\title{
Mitigation of sea level rise effects by addition of sediment to shrimp ponds
}

\author{
L. Della Patrona ${ }^{1, *}$, B. Beliaeff ${ }^{1}$, T. Pickering ${ }^{2}$ \\ ${ }^{1}$ Ifremer, Lagons, Ecosystèmes et Aquaculture durable (LEAD/NC) BP 2059, 98846 Nouméa Cedex, New Caledonia \\ ${ }^{2}$ Secretariat of the Pacific Community-SPC Aquaculture Section, Private Mail Bag, Suva, Fiji Islands
}

\begin{abstract}
In New Caledonia barren salt-pans located landward to mangroves are used for the construction of shrimp ponds. The existing farms are jeopardized by the projected rise in the sea level, because the landward boundaries of ponds are situated at the elevation reached by spring tides. One low-cost strategy for mitigating the effects of sea level rise is to raise the level of the bottom of ponds. To test the effectiveness of such an adaptation, we built 4 experimental ponds in the low-lying zone of an existing 10 ha shrimp pond. The level of the bottom of 2 ponds was raised by adding about $15 \mathrm{~cm}$ of agricultural soil. Placing agricultural soil in the pond did not impair the functioning of the shrimp pond ecosystem. On the contrary, it resulted in unexpectedly better shrimp production in the 2 ponds with agricultural soils versus control ponds. We conclude that placing a layer of soil inside shrimp ponds is a promising strategy for maintaining the viability of shrimp ponds as the sea level rises.
\end{abstract}

KEY WORDS: Climate change - Sea-level rise - Shrimp pond · Sediment enhancement . Biogeochemistry $\cdot$ Infaunal assemblages $\cdot$ New Caledonia

Resale or republication not permitted without written consent of the publisher

\section{INTRODUCTION}

Farming of the Mexican blue shrimp Litopenaeus stylirostris (Stimpson, 1874) began experimentally in New Caledonia in the 1970 s and was commercialized during the 1980s, when research results were transferred to the private sector. Although the annual production of blue shrimp in New Caledonia of $2000 t$ represents only $0.05 \%$ of global shrimp production, it is important to the local economy. Indeed, shrimp farming is the leading agro-food export for New Caledonia, worth USD 28.2 million annually. It also generates valuable employment in remote rural areas (some 450 jobs altogether). The industry has the potential to double in size because there are suitable sites on the west and north coasts of New Caledonia for the construction of another 20 farms with 700 ha of ponds in total (Andrier 2004).

The industry in New Caledonia is evaluating whether the plans to expand production, and even existing production, may be affected by climate change (Gilman et al. 2006). There is concern that prolonged periods of warmer summer temperatures may cause thermal stress to blue shrimp, which were initially chosen to be farmed all year round in New Caledonia's temperature conditions, particularly in the cool season (17 to $18^{\circ} \mathrm{C}$ minima in ponds). In particular, sperm viability is adversely affected if Litopenaeus spp. male broodstock are held at culture temperatures $>26^{\circ} \mathrm{C}$ (Perez-Velazquez et al. 2001). On the other hand, warmer waters may provide opportunities to culture new species of shrimp, especially Penaeus monodon, P. semisulcatus and P. merguiensis, which presently have distributions mainly to the north of New Caledonia. The consequences of climate warming could lead to reassessment of the potential of these indigenous species, with prospects for selective breeding.

The projected effects of increased greenhouse gases on aquaculture are not limited to temperature 
changes. In the tropical Pacific, predicted effects include: changes in coastal currents, stratification of ponds due to changes in water temperature, increases in nutrients due to greater levels of runoff from more extreme rainfall events, acidification of seawater, sea-level rise and possibly cyclones of greater intensity (T. Pickering et al. unpubl.). For shrimp farming in New Caledonia, sea-level rise is projected to have the greatest impact, as many of the existing shrimp ponds are constructed in low-lying flat coastal lands, such as the salt-pan areas that form a depauperate buffer between the landward zone of mangrove areas and the hinterland of terrestrial vegetation. Natural channels (arroyos) are used to drain away pond discharge water and disperse it through the surrounding mangroves, which act as a natural biofilter.

A gradual rise in sea level will jeopardize the functioning of existing shrimp ponds in New Caledonia by progressively inhibiting: (1) discharge of pond water into the arroyos, (2) emptying ponds of water to harvest shrimp, and (3) the complete drying of ponds before re-stocking for several weeks to enhance oxidation of organic matter and other reduced substances. It is particularly important that ponds are thoroughly dried, and the soil tilled to re-oxygenate it, before re-filling for the next culture cycle. Failure to do this results in increased stress (e.g. toxicity from inorganic nitrogen sources) and higher bacterial loadings and pathogenic bacteria that can cause catastrophic crop failure (Boyd 1992).

However, these threats can be avoided or reduced by adaptive strategies to modify ponds. The most important of these modifications will be to raise the level of the bottom of ponds. This will prevent inundation of ponds left to dry by present-day spring flood tides, and inundation due to sea-level rise (the upper boundaries often correspond to the level reached by the $1.75 \mathrm{~m}$ high tides that occur during the full moon in summer). These tides regularly penetrate to cover about one-third of the ponds for 5 to $12 \mathrm{~d} \mathrm{mo}^{-1}$, limiting the efficiency of the 1 to $3 \mathrm{mo}$ period when ponds are left to dry. It has already become necessary to try to block the entry of water into ponds left to dry by placing small gates in pond outlets. In addition, water remaining in puddles is actively pumped away.

A $15 \mathrm{~cm}$ layer of soil added to the bottom of ponds would be sufficient to limit inundations of present low-laying salt pan ponds by the highest spring tides. It would also make ponds resistant to sea-level rise until 2035, based on the sea-level rise projected in the Fourth Assessment Report of the Intergovern- mental Panel on Climate Change, which predicts the sea level will rise by 20 to $35 \mathrm{~cm}$ by 2035 (Ganachaud et al. in press). Extensive technical and scientific literature exists on layer placement of dredged material on salt marshes (Ray 2007), but not for soil placed directly in shrimp ponds. However, increased yields obtained by shrimp farmers in Vanuatu and Australia in newly constructed ponds on agricultural land encourage us to experiment with raising the level of the bottoms of shrimp ponds in New Caledonia with fresh soil. Here we report on an experiment examining the effects of placing $15 \mathrm{~cm}$ of agricultural soil in shrimp ponds on the growth and survival of blue shrimp, on the water column characteristics within ponds, and on the biogeochemistry of new sediments, including infauna, during semi-intensive farming of shrimp until they reached market size.

\section{MATERIALS AND METHODS}

\section{Field survey}

AM Farm, a recent 30 ha industrial semi-intensive shrimp farm with moderate densities and good feeding management, was selected because of the proximity to Ifremer laboratory facilities (Boulouparis, New Caledonia). This farm operates three 10 ha ponds built to the rear of the mangrove area in the intertidal zone. Four experimental ponds ( 0.2 ha) were constructed (dykes, inlets and outlets) inside the central homogenous zone of 1 of these three 10 ha ponds. The level of the bottom of 2 experimental (TL) ponds TL1 (3337 $\left.\mathrm{m}^{2}\right)$ and TL2 (2566 $\left.\mathrm{m}^{2}\right)$ was raised by adding about $15 \pm 2 \mathrm{~cm}$ (based on level marks previously spread over the area) of agricultural soil, while the 2 other experimental ponds CT1 $\left(2462 \mathrm{~m}^{2}\right)$ and CT2 $\left(2463 \mathrm{~m}^{2}\right)$ were not modified and were used as controls (CT). The required volume of agricultural soil was provided by scraping off surface material from an uncultivated field near the farm and mixing it well to ensure homogeneity. Blue shrimp Litopenaeus stylirostris post-larvae were introduced $10 \mathrm{~d}$ after the 4 experimental ponds were filled (28 December 2006) at the semi-intensive densities of 17.8 to 17.9 ind. $\mathrm{m}^{-2}$ commonly used in New Caledonia shrimp farming. Shrimps were reared for about 19 wk (119 to $127 \mathrm{~d}$ ) according to best management practices and harvested when they reached commercial size (18.5 to $21.9 \mathrm{~g}$ ) between 26 April 2007 and 3 May 2007 (Table 1). Water renewal varied from 0 to $20 \% \mathrm{~d}^{-1}$, depending on shrimp biomass, and progressively increased with time. Artificial feeding 
Table 1. Technical features of shrimp rearing in control (CT) and treatment (TL, raised bottom) ponds

\begin{tabular}{|ccccccc|}
\hline Pond & $\begin{array}{c}\text { Initial density } \\
\text { (ind. } \mathrm{m}^{-2} \text { ) }\end{array}$ & $\begin{array}{c}\text { Duration } \\
(\mathrm{d})\end{array}$ & $\begin{array}{c}\text { Food conversion } \\
\text { ratio }\end{array}$ & $\begin{array}{c}\text { Final weight } \\
(\mathrm{g})\end{array}$ & $\begin{array}{c}\text { Survival } \\
(\%)\end{array}$ & $\begin{array}{c}\text { Final biomass } \\
\left.(\mathrm{g} \mathrm{C} \mathrm{m})^{-2}\right)\end{array}$ \\
\hline CT1 & 17.9 & 120 & 2.05 & 19.8 & 38.9 & 14.8 \\
CT2 & 17.9 & 127 & 2.23 & 21.9 & 35.4 & 14.9 \\
TL1 & 17.8 & 119 & 1.86 & 18.5 & 50.5 & 17.8 \\
TL2 & 17.9 & 126 & 2.02 & 20.1 & 42.5 \\
\hline
\end{tabular}

(pelleted food with an estimated carbon content of $42.1 \% \mathrm{~g}^{-1}$ dry $\mathrm{wt}$ ) was provided in all the ponds. Feeding rates ranged from about $6 \mathrm{~kg} \mathrm{ha}^{-1} \mathrm{~d}^{-1}$ at the time of introduction of post-larvae to about $60 \mathrm{~kg} \mathrm{ha}^{-1}$ $\mathrm{d}^{-1}$ before shrimp harvesting. Shrimps were sampled weekly by castnet to check growth and to obtain rough estimates of survival.

\section{Water and sediment sampling}

Sampling was carried out once a week at 8:00 h at each pond station throughout the growing cycle. Sampling began immediately after filling the ponds with seawater and stopped just before harvesting. Two samplings were carried out before introduction of larvae. Due to the homogenous nature of both substrates (mixed agricultural soil, central area of a 10 ha semi-intensive pond lacking high organic matter accumulation) and the small size of the experimental ponds, a single station was located in the middle of each experimental pond away from the direct influence of the inlet water current. Furthermore, to allow comparison between the weekly samples, it was necessary to collect them in the same area (station), but not in exactly the same place in order to avoid disturbance (stamping) resulting from the previous sampling.

No significant spatial variability in the water column was observed except for mineral matter concentrations (not shown here), suggesting that the water column was well mixed and that a single sampling was representative of the whole pond.

At the time of sampling, the following parameters were measured in the water column: temperature, $\mathrm{pH}$, salinity and dissolved oxygen. Water samples were collected using a 21 polyethylene bottle for analysis of chlorophyll a ( $\mathrm{chl}$ a), ammonium, turbidity and alkalinity in the laboratory.

Temperature, dissolved oxygen (DO) and $\mathrm{pH}$ were recorded in situ (10 $\mathrm{cm}$ above the bottom) with portable oxygen and pH meters (WTW oxi 315i and WTW pH 340i). Salinities were measured in situ using an Atago hand refractometer.
For chl a, water samples ranging from 25 to $50 \mathrm{ml}$ were filtered through Whatman GF/F filters and analyzed by the classical fluorometric method before and after acidification (Holm-Hansen et al. 1965). The fluorometer (Turner TD700) was calibrated using pure chl a (Sigma). Ammonium was measured using the method described by Aminot \& Chaussepied (1983). Turbidity was measured with a handheld field fluorometer-turbidimeter. Alkalinity was determined according to the method described by Strickland \& Parsons (1972).

In the sediment, the parameters measured were: redox potential, $\mathrm{pH}$ easily oxidized material (EOM), sediment oxygen demand (SOD), total organic matter (OM), chl $a$, abundance of bacteria and meiofauna (abundance and biomass). At each station, 3 sediment cores were hand collected by means of a PVC plastic tube (25 cm in diameter and $5 \mathrm{~cm}$ long). In the cores, 10 to 50 (often necessary to reach a stable value in the field) measurements of the redox potential were immediately carried out with a microredox electrode ( $\mathrm{pH} / \mathrm{mv}$ meter WTW 315i). $\mathrm{pH}$ was measured directly in the wet sediment (ISFET Fisher Scientific ).

Three sediment samples for meiofaunal analysis were collected from the upper $2 \mathrm{~cm}$ of this core; about $50 \mathrm{~cm}^{3}$ of sediment was collected and immediately preserved by freezing. Each sample was passed through 1000 and $250 \mu \mathrm{m}$ (large meiofauna, LM) then 250 and $40 \mu \mathrm{m}$ sieves. Meiofauna were sorted from the $40 \mu \mathrm{m}$ fraction (small meiofauna, SM), counted, and identified to the highest possible taxonomic level. Meiofaunal biomass was estimated from size measurements of different animals. The length and width of up to 30 organisms per major taxon were measured from each core using a dissecting microscope fitted with a micrometer scale. These measurements were used for further conversion into biomass, using the specific conversion factors for each taxonomic group. Details of measurements can be found in Nozais et al. (2005).

Samples for bacterial counting $\left(\sim 20 \mathrm{~cm}^{3}\right)$ were immediately fixed with buffered formaldehyde $(2 \%$ final concentration) and stored at $4{ }^{\circ} \mathrm{C}$ until bacterial counting was carried out. For counting, sediment 
sub-samples were sonified 3 times (Bioblock vibro cell $75185 ; 60 \mathrm{~W}$ for $1 \mathrm{~min}$ ) and diluted to $1 / 2000$ with sterile and $0.2 \mu \mathrm{m}$ pre-filtered formaldehyde $(2 \%$ final concentration). Sub-samples were then stained for 30 min with DAPI $\left(4^{\prime}\right.$, 6 -diamidino-2-phenylindole dihydrochloride, $2500 \mu \mathrm{g}$ DAPI $\mathrm{l}^{-1}$ final concentration) and filtered on black polycarbonate (pore size $0.2 \mu \mathrm{m}_{i}$ Nuclepore) filters. The filters were analyzed as described by Epstein \& Rossel (1995) using epifluorescence microscopy (Leica DLMN 1000). For each slide, at least 10 microscope fields were observed, and a total of at least 300 cells was counted. Bacterial abundance was converted to dry weight after desiccation $\left(60^{\circ} \mathrm{C}\right.$ for $\left.24 \mathrm{~h}\right)$.

$\mathrm{Chl} a$ and phaeopigments were extracted from $\sim 1 \mathrm{~g}$ of dark, defrosted sediment with $5 \mathrm{ml}$ of methanol; they were analyzed fluorometrically in order to determine chl $a$ and were subsequently acidified with $200 \mu \mathrm{l}$ of $0.1 \mathrm{~N} \mathrm{HCl}$ to estimate phaeopigments (Lorenzen \& Jeffrey 1980).

Concentrations of $\mathrm{OM}$ were determined by ignition of the dry sediment at $350^{\circ} \mathrm{C}$ for $8 \mathrm{~h}$ (Queiroz \& Boyd 1998). The EOM analyses were carried out using the procedure adapted from Avnimelech et al. (2004). Sediment oxygen demand at $25^{\circ} \mathrm{C}$ over a period of $5 \mathrm{~d}$ in the dark (SOD5) was measured using a BOD meter WTW Oxytop apparatus. Slurry samples were also collected at the water-sediment interface for sulphide analysis according to the method developed by Fonselius (1985). The flocculent layer was carefully pumped into $250 \mathrm{ml}$ bottles through a silicone tubing network and stored in $50 \mathrm{ml}$ flasks, which were then purged with nitrogen gas. Protein (PRT) concentration was determined on sediment subsamples according to Hartree (1972). Protein concentrations were expressed as bovine serum albumin (BSA) equivalents. Total carbohydrates $(\mathrm{CHO})$ were analyzed according to Gerchakov \& Hatcher (1972) and expressed as glucose equivalents. Total lipids (LIP) were extracted from the sediment by direct elution with dichloromethane-ethanol $(60: 40 \%)$ modified from Bligh \& Dyer (1959) and then determined according to Marsh \& Weinstein (1966). Analyses were performed spectrophotometrically. For each biochemical assay, blanks were obtained using pre-combusted sediments $\left(450^{\circ} \mathrm{C}\right.$ for $\left.4 \mathrm{~h}\right)$. All analyses were performed in 3 to 5 replicates on $\sim 1 \mathrm{~g}$ of sediment.

\section{Statistical analysis}

For each parameter, mean comparisons between treatments (control vs. raised bottom) were made by means of ANCOVA (e.g. Draper \& Smith 1998). The model is the sum of the treatment effect, a linear trend including a quadratic term to account for parabolic-shaped signals, the Time $\times$ Treatment interactions and the pond effect nested in the treatment effect were analyzed to check for large differences between ponds within a treatment. Such large differences would lead to difficulties in the treatment effect comparisons. In the case of possible Time $\times$ Treatment interactions, the differences in orders of magnitude of mean squares were assessed and the corresponding graphics were visualized for more relevant comments in the 'Results' and 'Discussion' sections. The significance threshold was set to $\alpha=0.05$. For descriptive statistics, we computed means with sample standard deviations (SD). We used S-plus statistical software (TIBCO Software).

\section{RESULTS}

The ANCOVA results are presented in Table 2, and are subsequently commented on. Table 3 presents the detailed output of the ANCOVA results for PRT.

\section{Water column physico-chemical characteristics}

Temperatures averaged $\sim 27^{\circ} \mathrm{C}$ at all stations (Table 4). The highest temperatures were near the middle of the growing cycle in February. The ponds were slightly hypersaline with average salinities of

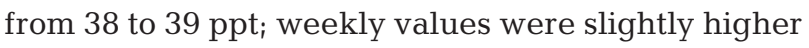
than $40 \mathrm{ppt}$ at the beginning of the survey, when a maximum of $\sim 42 \mathrm{ppt}$ was recorded in pond TL1. The same trend was observed in the 4 ponds for DO. Values decreased slightly from Week 1 to 12 , from 4.5 to $\sim 3 \mathrm{mg} \mathrm{l}^{-1}$. A minimum of $2.5 \mathrm{mg} \mathrm{l}^{-1}$ was recorded in pond TL1 (Week 10). From Week 13 to the end of rearing, oxygen concentrations rapidly increased to $6.5 \mathrm{mg} \mathrm{l}^{-1}$ (Week 18). Mean values were not different between treatments.

Water $\mathrm{pH}$ measured at 8:00 $\mathrm{h}$ stabilized in the range between 7.9 and 8.2 throughout the experiment, with the exception of pond CT2 which showed wider variations with a peak at 8.4 (Week 12). The $\mathrm{pH}$ mean values differed significantly between treatments, with control ponds showing higher values than raised-bottom ponds (Tables $2 \& 4$ ).

Alkalinity time-series patterns were very similar in both treatments. Whereas in the treatment ponds 
Table 2. ANCOVA results (with pond nested in treatment) for sediment and water column biogeochemical parameters and for meiofauna parameters. S: significant effect $(\alpha=5 \%)$; I: significantly different coefficient values between treatments $(\alpha=5 \%)$ for the linear trend and/or the quadratic term accounting for a possible parabolic signal; TL: treatment ponds; CT: control ponds; Redox: redox potential; EOM: easily oxidized material; SOD5: sediment oxygen demand over $5 \mathrm{~d}$ in the dark; OM: organic matter; PRT: protein; CHO: carbohydrate; LIP: lipid

\begin{tabular}{|c|c|c|c|c|}
\hline Parameter & Treatment & $\begin{array}{l}\text { Pond } \\
\text { (Treatment) }\end{array}$ & $\begin{array}{l}\text { Linear } \\
\text { trend }\end{array}$ & $\begin{array}{l}\text { Quadratic } \\
\text { term }\end{array}$ \\
\hline \multicolumn{5}{|l|}{ Sediment } \\
\hline Redox & & $\mathrm{S}$ & I & I \\
\hline $\mathrm{pH}$ & & $\mathrm{S}$ & $\mathrm{S}$ & \\
\hline EOM & $\mathrm{TL}>\mathrm{CT}$ & & $\mathrm{S}$ & I \\
\hline SOD5 & & $\mathrm{S}$ & $\mathrm{S}$ & I \\
\hline OM & & $\mathrm{S}$ & & I \\
\hline Chlorophyll a & $\mathrm{TL}<\mathrm{CT}$ & & I & \\
\hline Phaeopigments & $\mathrm{TL}<\mathrm{CT}$ & $\mathrm{S}$ & $\mathrm{I}$ & \\
\hline PRT & $\mathrm{TL}>\mathrm{CT}$ & $\mathrm{S}$ & $\mathrm{S}$ & I \\
\hline $\mathrm{CHO}$ & $\mathrm{TL}>\mathrm{CT}$ & $\mathrm{S}$ & $\mathrm{I}$ & $\mathrm{I}$ \\
\hline LIP & & $\mathrm{S}$ & $\mathrm{S}$ & \\
\hline \multicolumn{5}{|l|}{ Sulphides } \\
\hline \multicolumn{5}{|l|}{ Water column } \\
\hline Temperature & & & & $\mathrm{S}$ \\
\hline Alkalinity & $\mathrm{TL}<\mathrm{CT}$ & & $\mathrm{S}$ & $\mathrm{S}$ \\
\hline Salinity & & & $\mathrm{S}$ & I \\
\hline $\mathrm{pH}$ & $\mathrm{TL}<\mathrm{CT}$ & & $\mathrm{S}$ & $\mathrm{S}$ \\
\hline Oxygen & & & $\mathrm{S}$ & $\mathrm{S}$ \\
\hline Turbidity & & & $\mathrm{S}$ & $\mathrm{S}$ \\
\hline Ammonium & & & I & \\
\hline \multicolumn{5}{|l|}{ Meiofauna } \\
\hline Ciliates & & $\mathrm{S}$ & $\mathrm{S}$ & \\
\hline Copepods & $\mathrm{TL}<\mathrm{CT}$ & & $\mathrm{I}$ & I \\
\hline Nematodes & $\mathrm{TL}<\mathrm{CT}$ & & & $\mathrm{S}$ \\
\hline Foraminifers & $\mathrm{TL}<\mathrm{CT}$ & & $\mathrm{S}$ & I \\
\hline Rotifers & & $\mathrm{S}$ & $\mathrm{S}$ & I \\
\hline
\end{tabular}

alkalinity remained constant at 2.5 meq $\mathrm{l}^{-1}$ during the 19 wk experiment, in the controls it increased regularly from 2.3 to 2.9 meq $\mathrm{l}^{-1}$ (Week 12), then sharply decreased to 2.4 meq $^{-1}$ at the end of the experiment (Table 4). No statistically significant difference was found between treatments $(p>0.05$; Table 2$)$.
Table 3. Detailed output of the ANCOVA results for proteins. Effects are treatment (control vs. raised bottom), temporal trend (Time $\times$ Treatment) with a quadratic term $\left(\right.$ Time $^{2}$ ) and corresponding interaction terms with Treatment and the pond effect nested in Treatment (df: degrees of freedom).

${ }^{*}$ Significant at $\mathrm{p}<0.05$

\begin{tabular}{|lcccc|}
\hline Effect & df & $\begin{array}{c}\text { Mean } \\
\text { squares }\end{array}$ & $F$ & $\begin{array}{c}\mathrm{p} \\
(F)\end{array}$ \\
\hline Treatment & 1 & $1.5 \times 10^{8}$ & 136.0 & $<10^{-7 *}$ \\
Time & 1 & $1.5 \times 10^{7}$ & 14.1 & $0.0002^{*}$ \\
Time $^{2}$ & 1 & $5.2 \times 10^{6}$ & 4.8 & 0.03 \\
Treatment $\times$ Time $^{2}$ & 1 & $1.7 \times 10^{6}$ & 1.6 & 0.21 \\
Treatment $\times$ Time & 1 & $1.5 \times 10$ & 1.4 & 0.23 \\
Pond(Treatment) & 2 & $7.6 \times 10^{6}$ & 7.1 & $0.001^{*}$ \\
Residuals & 393 & $1.1 \times 10^{6}$ & & \\
\hline
\end{tabular}

Turbidity trends were characterized by an overall increase during the shrimp culture cycle in all 4 enclosures (Table 4).

Ammonium in the water remained low at $\sim 0.1 \mu \mathrm{M}$ $\mathrm{l}^{-1}$ in all 4 ponds until Week 12 when it peaked at $2.0 \mathrm{\mu M} \mathrm{l}^{-1}$ (with the exception of pond TL2; Table 4) simultaneously with a collapse in the phytoplankton bloom (determined by a sharp decrease in $\operatorname{chl} a$ concentration and phytoplankton cell counting, not shown here) following heavy rains (indicated by a sharp drop in salinity). No statistically significant differences were found between treatments (Table 2).

\section{Phytopigments}

CT and TL ponds showed the same trend for phytopigment chl a and phaeopigments during the shrimp culture cycle, and the ratio phaeopigments to total pigment averaged $20 \%$ in both treatments. Pigment concentrations remained low during the first $7 \mathrm{wk}$, then increased until Week 12, to 25 and $6 \mu \mathrm{g} \mathrm{l^{-1 }}$ for chl $a$ and phaeopigments, respectively. Chl a concentration fell to $<5 \mu \mathrm{g} \mathrm{l}^{-1}$ in Week 14 and then increased slightly. Chl $a$ and phaeopigment con-

Table 4. Water column physico-chemical parameters. Mean values (SD in parentheses) in control (CT) and treatment (TL) ponds recorded throughout the growing cycle (12 December 2006 to 11 April 2007). No statistical differences were found between treatments ( $p>0.05$ ). NTU: nephelometer turbidity units

\begin{tabular}{|cccccccccc|}
\hline Pond & $\begin{array}{c}\text { Temperature } \\
\left({ }^{\circ} \mathrm{C}\right)\end{array}$ & $\begin{array}{c}\text { Salinity } \\
(\mathrm{ppt})\end{array}$ & $\begin{array}{c}\text { Dissolved oxygen } \\
\left(\mathrm{mg} \mathrm{l}^{-1}\right)\end{array}$ & $\begin{array}{c}\text { Water } \\
\mathrm{pH}\end{array}$ & $\begin{array}{c}\text { Alkalinity } \\
\left(\mathrm{meq} \mathrm{l}^{-1}\right)\end{array}$ & $\begin{array}{c}\text { Turbidity } \\
(\mathrm{NTU})\end{array}$ & $\begin{array}{c}\text { Ammonium } \\
\left(\mu \mathrm{mol}^{-1}\right)\end{array}$ & $\begin{array}{c}\text { Chlorophyll a Phaeopigments } \\
\left(\mu \mathrm{l}^{-1}\right)\end{array}$ \\
\hline $\mathrm{CT} 1$ & $26.9(2.6)$ & $38.4(1.8)$ & $4.5(1.1)$ & $8.10(0.01)$ & $2.56(0.01)$ & $15.6(8.5)$ & $0.23(0.24)$ & $8.3(6.0)$ & $1.9(1.9)$ \\
CT2 & $26.9(2.6)$ & $38.6(1.8)$ & $4.6(1.3)$ & $8.14(0.01)$ & $2.56(0.02)$ & $16.3(8.2)$ & $0.44(0.52)$ & $8.9(7.0)$ & $2.5(3.1)$ \\
TL1 & $27.0(2.7)$ & $38.9(3.5)$ & $4.3(1.1)$ & $8.04(0.01)$ & $2.52(0.00)$ & $13.1(7.4)$ & $0.26(0.16)$ & $8.7(6.1)$ & $2.3(2.2)$ \\
TL2 & $26.8(2.7)$ & $38.5(2.0)$ & $4.4(1.1)$ & $8.00(0.01)$ & $2.49(0.00)$ & $14.6(7.2)$ & $0.11(0.10)$ & $10.2(7.5)$ & $1.6(1.4)$ \\
\hline
\end{tabular}



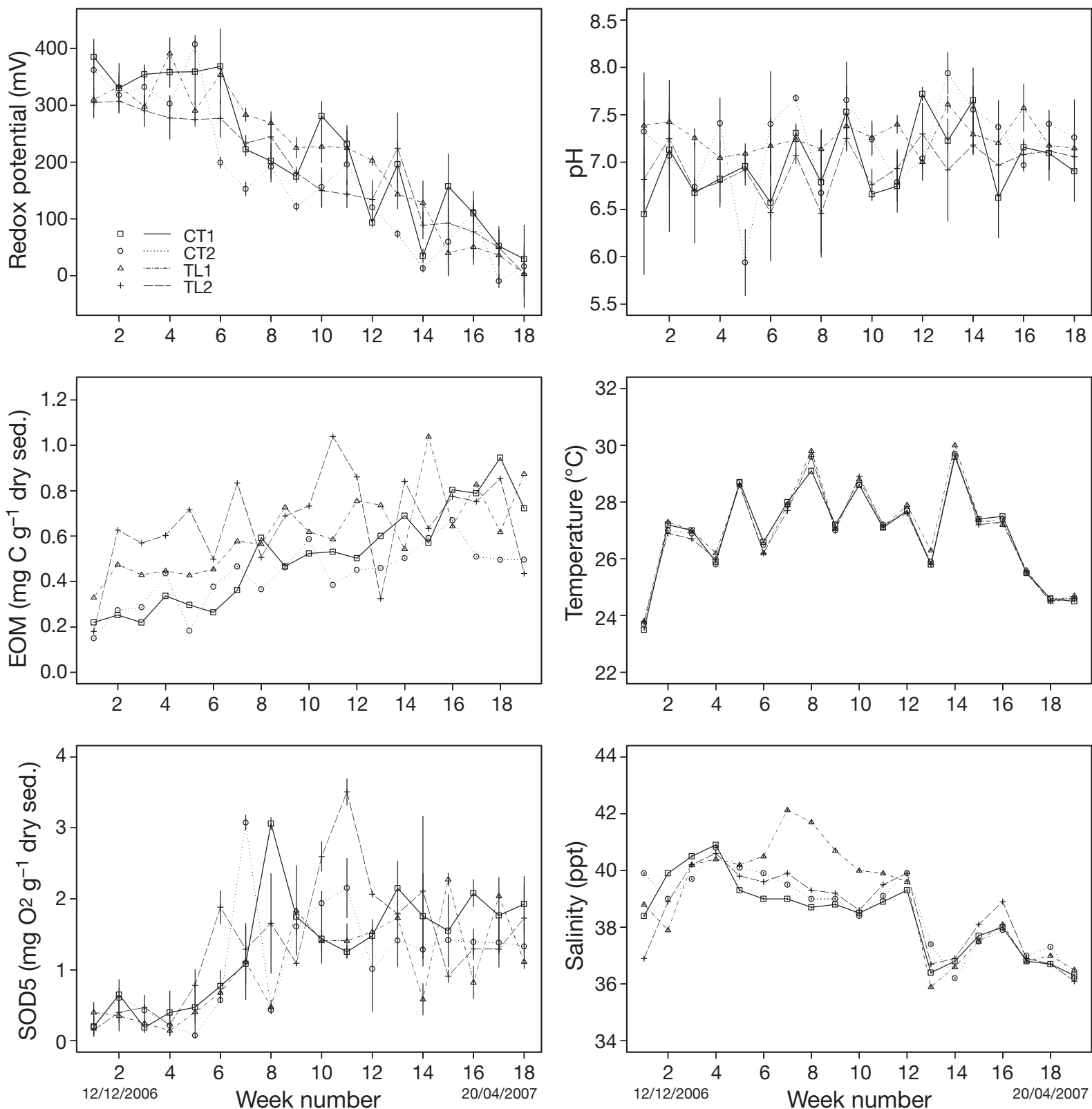

Fig. 1. Changes in sediment physico-chemical parameters over time (12 December 2006 to 20 April 2007) in control (CT) and treatment (TL) ponds, showing the general trends to be similar in all 4 ponds. EOM: easily oxidized material; SOD5 sediment oxygen demand over $5 \mathrm{~d}$ in the dark. Analyses for redox and $\mathrm{pH}$ were not available for Week 19 and failed for SOD for this week

centrations were not statistically different between treatments.

\section{Sediment characteristics}

During the rearing course, the main trend in active oxygen demanding pool parameters (Avnimelech et al. 2004) was a steady decrease of redox and a simultaneous increase of EOM and SOD (Fig. 1). No statis- tically significant differences were found between treatments for SOD and sulphides, but EOM values differed, with TL ponds showing the highest values (Tables 2 \& 5). Weekly measurements of OM ranged from 26 to $41 \mathrm{mg} \mathrm{g}^{-1}$ in the ponds without any discernible trend during the culture cycle.

In all ponds, $\mathrm{pH}$ values at the beginning and the end of the survey were nearly identical. While $\mathrm{pH}$ values in TL ponds remained very stable, those of CT ponds showed fluctuations (Fig. 1). There was a 


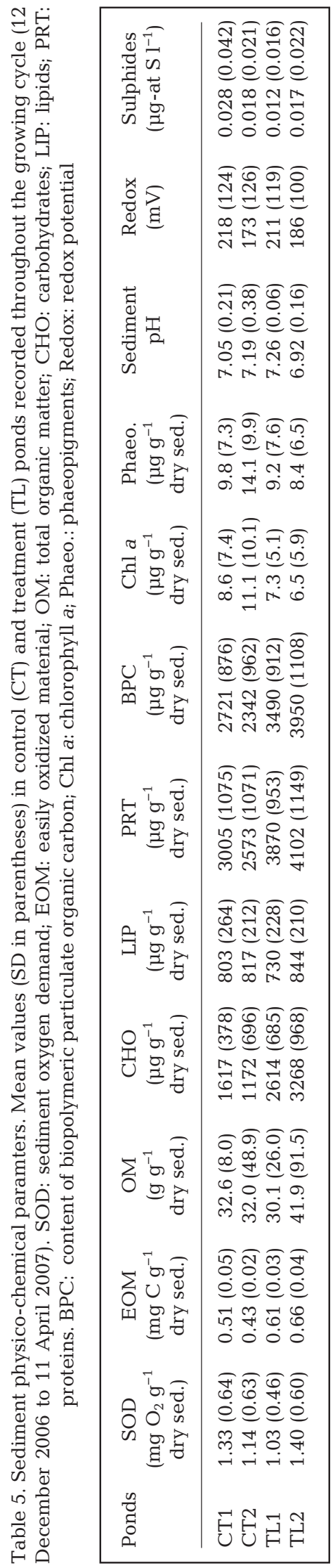

statistically significant $(p<0.05)$ difference in mean $\mathrm{pH}$ values between treatments, with $\mathrm{CT}$ ponds having higher values than TL ponds (Tables $2 \& 5$ ).

$\mathrm{CHO}, \mathrm{PRT}$ and LIP concentration changes were irregular, and no trend was discernible in the timeseries data. CHO and PRT content of sediments was significantly higher in TL ponds $(p<0.05)$, whereas LIP values were not significantly different between treatments (Tables $2 \& 5$ ).

During the growing cycle, microphytobenthos exhibited slight increases in chloroplastic pigment content in all ponds (Fig. 2). Significantly higher phytopigment concentrations were recorded in CT ponds (Tables $2 \& 5$ ).

\section{Benthic bacteria and meiofauna}

Mean $( \pm \mathrm{SD})$ bacterial densities in sediments were nearly identical in the ponds, with $2.5 \pm 1.5,2.7 \pm 1.6$, $2.7 \pm 1.9,2.70 \pm 1.7 \times 10^{9} \mathrm{ml}^{-1}$ sediment recorded in CT1, CT2, TL1 and TL2, respectively. Composition of bacteria was quite similar between ponds. Among the morphotypes, Coccus spp. dominated the total abundance of bacteria $(>70 \%)$. Sediment bacterial abundance showed the same temporal pattern in all 4 ponds.

Data on SM $(40-250 \mu \mathrm{m})$ and LM $(250-1000 \mu \mathrm{m})$ meiofaunal abundances are reported in Table 6. In the experimental ponds, meiofauna (protista and metazoans) were composed of 13 groups: foraminifera, ciliates, other protozoans, rotifers, kinorhynchs, nematodes, polychaetes, oligochaetes, mites, nauplii, copepods, ostracods, tardigrades and chirono-

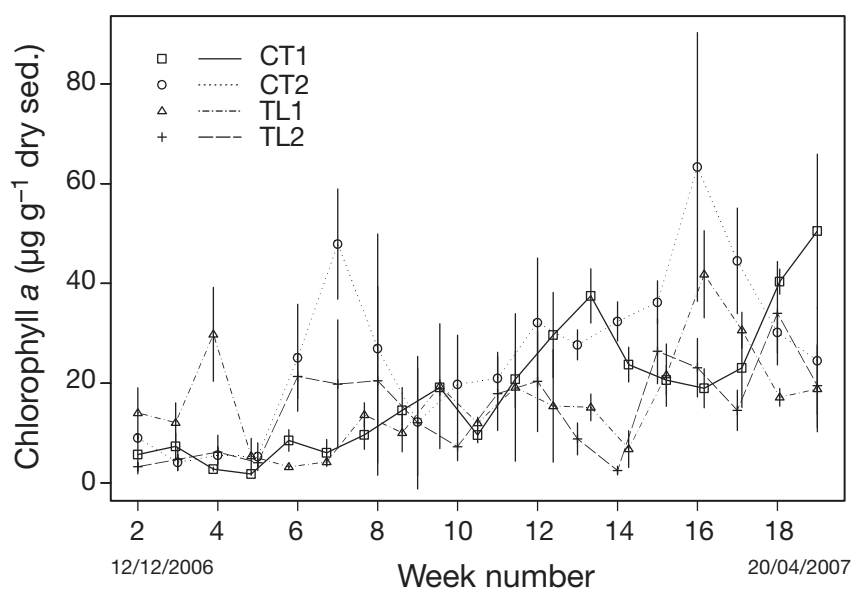

Fig. 2. Total phytopigment concentrations (mean \pm SD). Temporal variations (12 December 2006 to 20 April 2007) of chlorophyll $a$ in control (CT) and treatment (TL) ponds during the growing cycle. Analyses were not performed for Week 1 
Table 6. Meiofaunal abundances. Mean values (SD in parentheses; ind. $10 \mathrm{~cm}^{-2}$ ) of small (SM; $\left.40-250 \mu \mathrm{m}\right)$ and large (LM; 250-1000 $\mu \mathrm{m}$ ) size classes in control (CT) and treatment (TL) ponds

\begin{tabular}{|c|c|c|c|c|c|c|c|c|}
\hline \multirow[t]{2}{*}{ Taxon } & \multicolumn{2}{|c|}{ CT1 } & \multicolumn{2}{|c|}{ CT2 } & \multicolumn{2}{|c|}{ TL1 } & \multicolumn{2}{|c|}{ TL2 } \\
\hline & SM & LM & SM & LM & SM & LM & SM & LM \\
\hline Foraminifera & $87(76)$ & & 99 (68) & & $20(39)$ & & $12(27)$ & \\
\hline Ciliates & $233(153)$ & $0.1(0.1)$ & $273(170)$ & $0.7(1)$ & $305(214)$ & $0.5(1)$ & $106(148)$ & $0.0(0.2)$ \\
\hline Rotifers & $14(23)$ & & $26(21)$ & & $34(34)$ & & $8(6)$ & \\
\hline Kinorhynchs & & & & & $0.2(2)$ & & & \\
\hline Nematodes & $145(101)$ & $0.7(1)$ & $170(91)$ & $0.9(1)$ & $126(103)$ & 1 (3) & $84(82)$ & $0.3(0.7)$ \\
\hline Polychaetes & $1(3)$ & $0.1(0.1)$ & $0.6(2)$ & $0.1(0.3)$ & $0.1(0.8)$ & $0.1(0.2)$ & $0.2(0.9)$ & $0.1(0.2)$ \\
\hline Oligochaetes & $0.7(2)$ & $0.2(0.3)$ & $0.5(2)$ & $0.1(0.1)$ & $0.3(2)$ & $0.0(0.1)$ & $0.6(2)$ & $0.0(0.1)$ \\
\hline Mites & & $0.1(0.2)$ & & $0.0(0.1)$ & $0.8(2)$ & $0.1(0.1)$ & $0.4(1)$ & $0.0(0.1)$ \\
\hline Nauplii & $27(24)$ & & $24(42)$ & & $11(8)$ & & $26(18)$ & \\
\hline Copepods & $18(18)$ & $0.8(1)$ & $27(40)$ & $0.7(0.7)$ & $25(29)$ & $0.8(0.9)$ & $10(16)$ & $0.5(1.0)$ \\
\hline Ostracods & & $0.0(0.0)$ & & & & $0.0(0.1)$ & & \\
\hline Tardigrades & $0.1(0.8)$ & & & & & & & \\
\hline Chironomids & & $0.1(0.1)$ & $0.0(0.1)$ & & & $0.0(0.1)$ & & \\
\hline Total abundance & 497 (546) & $2(3)$ & $581(643)$ & $3(3)$ & 496 (603) & $3(4)$ & $256(281)$ & $1(1)$ \\
\hline
\end{tabular}

mids. Meiofauna comprised $>99 \%$ of the individuals between 40 and $250 \mu \mathrm{m}$ in size (i.e. small meiofauna).

Ciliates and other protozonans were the most numerous groups $(50.4 \%)$ in pond bottom sediments. Nematodes constituted the second most abundant taxon $(25.3 \%)$. Harpacticoid copepods (including nauplii) were the third most important meiofaunal group $(9.8 \%)$. Protozoa, ciliates and rotifers were significantly less abundant in TL2 than in other ponds. The lowest abundances of foraminifers, nematodes and harpacticoid copepods were observed in TL versus CT ponds.

The principal meiofaunal taxa showed similar temporal patterns across the different ponds. Whatever the taxon or the pond, abundances increased until mid-crop, then decreased to the end of the culture cycle (Fig. 3).

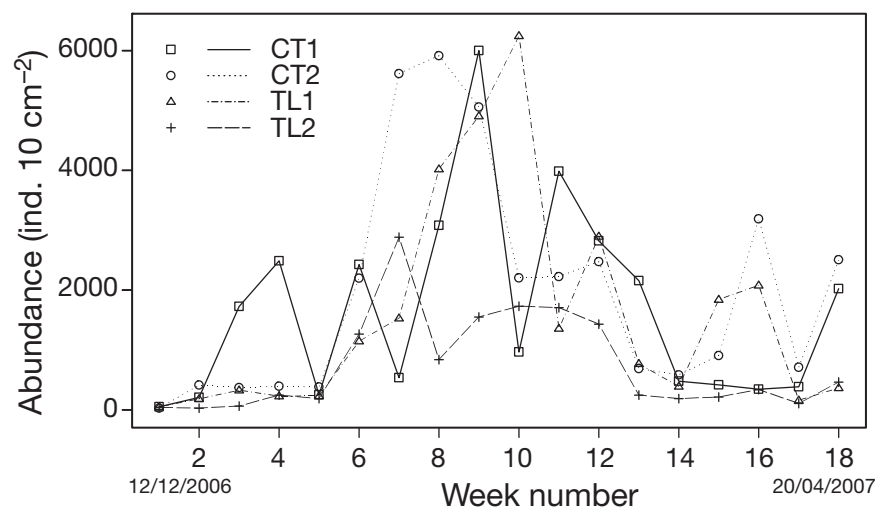

Fig. 3. Meiofaunal abundance (mean $\pm \mathrm{SD}$ ). Temporal variations (12 December 2006 to 20 April 2007) in control (CT) and treatment (TL) ponds during the growing cycle. Alcohol preservation failed for Week 19 samples

\section{Shrimp growth and survival}

Rearing in raised-bottom ponds led to better shrimp production data in terms of extrapolated yield (4765 vs. $4090 \mathrm{~kg} \mathrm{ha}{ }^{-1} \mathrm{yr}^{-1}$ ) and survival (46.5 vs. $37.2 \%)$, a slightly better food conversion ratio (1.94 vs. 2.14), but slower growth (19.3 vs. $20.7 \mathrm{~g}$ final weight) (Table 1).

\section{DISCUSSION}

We demonstrated that the addition of a $15 \mathrm{~cm}$ layer of common agricultural soil in shrimp ponds had immediate positive effects, leading to better survival of shrimp, a better food conversion ratio and better yield, but slower growth. In this experiment, addition of the soil did not affect water quality, with the exception of $\mathrm{pH}$, which was slightly lower in ponds with raised bottoms, although it remained within the optimal range for Mexican blue shrimp Litopenaeus stylirostris (Clifford 1997). Similarly, there were few effects on the physical and chemical characteristics of the bottoms of experimental ponds. In particular, EOM, SOD5, redox potential and sulphide concentrations followed the same pattern in all 4 ponds, reinforcing the conclusion that the active sediment oxygen demanding pool (sensu Avnimelech et al. 2004) was not perturbed over the culture cycle by the added soil layer and did not impair shrimp health or survival. We hypothesized that the slower shrimp growth observed in TL ponds may be explained by reduced efficiency of meiofaunal colonization (Palmer 1988). In fact, organisms associated with pond sedi- 
ments comprise an important part of the diet of cultured blue shrimp and contribute to their growth and health. The evolution of stomach contents and comparison of abundance of meiofauna and preferential prey in guts led to the conclusion that $L$. stylirostris is with certainty an opportunist predator preying upon the most abundant meiofaunal taxa (Della Patrona et al. 2004). We would suggest that placement of new terrestrial soil on the pond bottom will negatively impact the development of meiofauna, because colonization of the 'unconditioned' environment is likely to be more difficult than in the substratum of mature shrimp ponds (Mirto \& Danovaro 2004). In drying pond environments, meiofauna can originate from several sources (Benzie 1984). Organisms could recover from dormant or semi-aquatic states (Ricci 2001) in the non-inundated part (landward) of the pond. Colonizers could also invade the seaward (i.e. most of the total area) pond area by way of frequent, mostly accidental, flooding with adjacent arroyo water containing mangrove litter. Larvae and adults could be sucked up by large seaward pumps taking in rafts of sea grass, algae and Rhizophora spp. leaf substrate (Smock 1994) and, before pond filling, would grow in supply channels acting as breeding reservoirs (Street \& Titmus 1979). We infer that the lower meiofaunal abundance found in raised-bottom ponds (TL) could be partially explained by the limited number of sources of meiofaunal propagation, i.e. solely the supply channels filled $2 \mathrm{wk}$ before beginning the experiment. Thus, the addition of common agricultural soil appears to be a good strategy, but it needs further improvement to boost meiofaunal colonization and development, at least for the first crop (Bazzanti et al. 2008).

In considering sources of soil for addition, the question arises as to whether different placement materials will have different effects (values or dynamics) and might negatively (or positively) impact on blue shrimp health and yield. In fact, substrate conditions are actually more critical for shrimp than for many other aquaculture species, because shrimp spend most of their time on the pond bottom and burrow into the sediment (Boyd 1992). Not only do substrates have their own inherent properties (e.g. grain size, mineral composition), but the substrate type also influences water quality by the transfer of nutrients and oxygen-demand between the soil and overlying water. Exposure to toxic materials in sediments reduces shrimp feeding, slows their growth, and makes them more susceptible to disease (Avnimelech \& Ritvo 2003). Several studies have assessed the chemical and physical characteristics of aquaculture pond soils (Boyd et al. 1994, Munsiri et al. 1996), but few authors have attempted to correlate pond bottom properties with shrimp production (Ritvo et al. 1998). Moreover, Yuvanatemiya \& Boyd (2006) reported that some ponds have better soil quality for shrimp production than others. So it may be relevant to supplement our findings, which are limited to agricultural soil originating from 1 source, by evaluating responses to processes occurring in the bottom soil and at the soil-water interface and evaluating cultured shrimp behaviour in response to the placement of various backfill materials. The best way to achieve this aim would be to use a battery of mesocosms, aquaria, or cages because of the high numbers needed for the objectives and design of the study (Chim et al. 2008). Nevertheless, shrimp behaviour and sediment processes in these 'model ponds' (tanks with false bottoms) are far from those observed in large, semi-intensive ecosystem ponds in an often biased (because of added aeration), natural environment. Furthermore, there is the question of the technical and economic feasibility of moving and spreading $15000 \mathrm{~m}^{3}$ of soil (i.e. the placement of a $15 \mathrm{~cm}$ layer material in a 10 ha pond), so reducing substrate categories. For this, scraping off 1000 s of cubic meters of adjacent intertidal salt pan surface would be highly expensive (soft bottom) and not permitted by the Melanesian people (customary law). Excavating the bottom sediment of existing shrimp ponds would be risky in view of the poor history of results (eutrophicated and/or abandoned ponds) and would be counter-productive for donor ponds with soil associated with high production (the aim would be to elevate, not excavate, the bottom). Finally, the use of cheap or free common agricultural soil scraped off cleared uncultivated fields, preferably in adequate quantities close to the shrimp, would be a less risky solution.

We suggest that accumulated sediments in arroyos should be investigated as possible backfill material in further research. These sediments originate both from the huge quantities of water discharge from ponds containing high concentrations of suspended mineral particles and low organic content during growing time and the internal black sludge flushed during harvesting (Avnimelech \& Ritvo 2003), primarily the latter. In New Caledonia, a negative effect of shrimp farm waste on the mangrove areas downstream of local farms is the infilling of drainage arroyos. This infilling limits pond drainage and leads to costly natural drain excavation and spoil removal, which could have negative environmental impacts (Virly et al. 2005). Reduced sediments found in inten- 
sively managed ponds may be detrimental to animal health (Avnimelech \& Zohar 1986). But if well managed, whether by resuspension (Hopkins et al. 1994), aeration and mixing (Avnimelech \& Ritvo 2001), or by spreading onto dry sediment, then sludge could be used to enhance pond productivity. Depositing a thin layer of dredged material on coastal marsh by means of high-pressure spray-dredging technology has been proposed as a mechanism to minimize the wetland impact associated with traditional bucketdredging technologies and to restore soil elevations in degraded marshes (Ford et al. 1999). If applied appropriately, sediment/slurry deposition can result in a rapid positive response by the vegetation (La Peyre et al. 2008). In this technique, sediment with a high water-to-solids ratio ( $85 \%)$ can be piped and spread over long distances (up to $1000 \mathrm{~m}$ ) (Ray 2007). Such use of hydraulic dredging technology in shrimp farming areas may have a double advantage; cost-effective clearing of high fluid-to-solids ratio sediments blocking arroyos will allow easier shrimp pond drainage and spraying the resulting slurry back into ponds will help to restore pond bottom elevation and offset sediment deficiencies such as low infaunal abundance.

New Caledonian farmers have built huge compacted dykes in the last decades on free lands. Thus, they would not consider abandoning such infrastructures in the next $30 \mathrm{yr}$ and risking the consequences of rising sea levels, at least in the lowest intertidal ponds. The question can be raised as to whether it might not be wiser to rebuild ponds having the same area (8 to $10 \mathrm{ha}$ ) on agricultural land that is at a higher altitude (at least $75 \mathrm{~cm}$ ). This option would only be feasible in the special case of perfectly flat land belonging to a developer, who would himself carry out the necessary excavation work. For the resurfacing of an ordinary field - so as to give it an adequate slope and not to leave depressions detrimental to the satisfactory harvesting of shrimp at the end of rearing - of an area of around 10 ha would be prohibitively costly. It must be appreciated that despite subsidies, New Caledonian aquaculture is barely profitable, due in particular to very high construction and labour costs, which are 3 to 10 times higher than those in Vanuatu or Madagascar (Anonymous 2003). Thus, from the start of this activity, the government has provided salt pans free of charge to shrimp farmers, whereas the price of agricultural land has constantly increased, largely because of pressure from building adjacent to the sea. However, the conversion into ponds of these impermeable sandy clay marshes gently sloping toward the sea limits the costs of excavation, in that the banked-up dykes are simply placed on the ground. In this respect, the most suitable strategy would be to use intensive blue shrimp culture in smaller ponds so as to recover the costs involved and to compensate for the reduction in the area available for ponds. With this in mind, 2 intensive culture systems could be considered: hyper-intensive ( 75 to 120 ind. $\mathrm{m}^{-2}$ ) culture of Litopenaeus stylirostris in concrete inland ponds, as successfully evaluated by McIntosh et al. (1999), and/or intensive (40 to 45 ind. $\mathrm{m}^{-2}$ ) rearing in higher elevation areas (3 to $4 \mathrm{ha}$ ) of existing but reshaped ponds, in the same way as the Thai shrimp culture practices evolved in the 1980s (Szuster 2006).

Intensification would involve several well-known risks; the most obvious being the outbreak and spread of diseases (Purwanto 1997). Moreover, in the face of tough international competition, New Caledonia has taken up the challenge of supplying farmed shrimp of outstanding quality to the export market. This was made possible by the unique and desirable organoleptic quality of the species produced, as well as the extensive rearing conditions, leading to healthier shrimp without shell defects (Andrier 2004). This position would be untenable if the intensification route were to be taken. Clearly, the strategy of producing a high-quality product by extensive practices in large ponds with raised bottoms, as proposed here, would be a preferable adaptation for mitigating the effects of the predicted sea level rise on shrimp farming in New Caledonia.

Acknowledgements. The authors thank the 2 anonymous reviewers for their thorough reviews and the suggestions that helped to greatly improve the manuscript. Thanks are also due to J. Bell (Secretariat of the Pacific CommunitySPC), who made constructive comments and suggestions. We are grateful to the editor, M. La Peyre, for her detailed editing and considerable improvement of the manuscript.

\section{LITERATURE CITED}

Aminot A, Chaussepied M (1983) Manuel des analyses chimiques en milieu marin. Centre national pour l'exploitation des océans,

Andrier P (2004) Une vision globale de l'aquaculture de crevettes et de son marché. In: Goarant C, Harache Y, Herbland A, Mugnier C (eds) Styli 2003: Trente ans de crevetticulture en Nouvelle Calédonie Ifremer Actes Colloq 38:18-22

Anonymous (2003) L'élevage de la crevette en zone tropicale. Centre pour le développement de l'entreprise, Brussels

Avnimelech Y, Ritvo G (2001) Aeration, mixing, and sludge control in shrimp ponds. Advocate 6:51-53

Avnimelech Y, Ritvo G (2003) Shrimp and fish soils: processes and management. Aquaculture 220:549-567 
Avnimelech Y, Zohar G (1986) The effect of local anaerobic conditions on growth retardation in fish pond sediment. Aquaculture 58:167-174

Avnimelech Y, Ritvo G, Kochva M (2004) Evaluating the active redox and organic fractions in pond bottom soils: EOM, easily oxidised material. Aquaculture 233:283-292

Bazzanti M, Grezzi F, Della Bella V (2008) Chironomids (Diptera) of temporary and permanent ponds in Central Italy: a neglected invertebrate group in pond ecology and conservation. J Freshwat Ecol 23:219-229

Benzie JAH (1984) The colonization mechanisms of stream benthos in a tropical river (Menik Ganga: Sri Lanka). Hydrobiologia 20:171-179

Bligh EG, Dyer WJ (1959) A rapid method of total lipid extraction and purification. Can J Biochem Physiol 37 : 911-917 Medline

Boyd CE (1992) Shrimp pond bottom soil and sediment management. In: Wyban J (ed) Proceedings of the special session on shrimp farming. World Aquaculture Society, Baton Rouge, LA, p 166-180

Boyd CE, Munsiri P, Hajek BF (1994) Composition of sediment from intensive shrimp ponds in Thailand. World Aquac 25:53-55

Chim L, Castex M, Pham D, Brun P and others (2008) Evaluation of floating cages as an experimental tool for marine shrimp culture studies under practical earthen pond conditions. Aquaculture 279:63-69

Clifford HC (1997) Standard operating manual for managing super shrimp ponds. Super shrimp, S.A. de C.V. technical services division

Della Patrona L, Chim L, Capo S, Lemaire P, Brun P, Martin JL (2004) Effect of mineral fertilization on food web development, abundance of ingested prey, growth rate and pelleted feed conversion ratio of the shrimp Litopenaeus stylirostris reared in earthen ponds in cold season. In: Book of abstracts, World Aquaculture Society Annual Conference, 1-5 March 2004, Honolulu, p 105

Draper NR, Smith H (1998) Applied regression analysis, 3rd edn. John Wiley \& Sons, New York, NY

Epstein SS, Rossel J (1995) Enumeration of sandy sediment bacteria: search of optimal protocol. Mar Ecol Prog Ser 117:289-298

Fonselius SH (1985) Determination of hydrogen sulfide. In: Grasshoff K, Ehrhardt M, Kremling K (eds) Methods of seawater analysis, 2nd edn. Verlag Chemie, Weinheim, p 73-81

Ford MA, Cahoon DR, Lynch JC (1999) Restoring marsh elevation in a rapidly subsiding salt marsh by thin layer deposition of dredged material. Ecol Eng 12:189-205

Ganachaud A, Sen Gupta A, Orr J, Wijffels S and others (in press) Observed and expected changes to the Pacific Ocean. In: Bell JD, Johnson JE, Hobday AJ (eds) Vulnerability of fisheries and aquaculture in the Pacific to climate change. Secretariat of the Pacific Community, Noumea

> Gerchakov MR, Hatcher PG (1972) Improved techniques for analysis of carbohydrates in sediments. Limnol Oceanogr 17:938-943

Gilman E, Van Lavieren H, Ellison J, Jungblut V and others (2006) Pacific Island mangroves in a changing climate and rising sea. UNEP regional seas reports and studies, No. 179. United Nations Environment Programme, Regional Seas Programme, Nairobi

Hartree EF (1972) Determination of protein: a modification of the Lowry method that gives a linear photometric response. Anal Biochem 48:422-427

Holm-Hansen O, Lorenzen CJ, Holmes PE, Strickland JDH (1965) Fluorometric determination of chlorophyll. J Con Int Explor Mer 30:3-15

> Hopkins JS, Browdy CL, Sandifer PA (1994) Sludge management in intensive pond culture of shrimp: effect of management regime on water quality, sludge characteristics, nitrogen extinction, and shrimp production. Aquac Eng 13:11-30

> La Peyre MK, Gossman B, Piazza BP (2008) Short- and longterm response of deteriorating brackish marshes and open-water ponds to sediment enhancement by thinlayer dredge disposal. Est Coast 32:390-402

Lorenzen C, Jeffrey SW (1980) Determination of chlorophyll in sea water. UNESCO Tech Pap Mar Sci 35:1-20

Marsh JB, Weinstein DB (1966) Simple charring method for determination of lipids. J Lipid Res 7:574-576 Medline

McIntosh RP, Drennan DP, Bowen BM (1999) Belize aquaculture: development of an intensive sustainable, environmentally friendly shrimp farm in Belize. In: Green BW, Clifford HC, McNamara M, Montaño GM (eds) 5th Central American Symposium on Aquaculture, Latin American Chapter of the World Aquaculture Society, August 18-20, San Pedro Sula, p 85-99

Mirto S, Danovaro R (2004) Meiofaunal colonisation on artificial substrates: a tool for biomonitoring the environmental quality on coastal marine systems. Mar Pollut Bull 48:919-926 Medline

- Munsiri P, Boyd CE, Teichert-Coddington D, Hajek BF (1996) Texture and chemical composition of soils from shrimp ponds near Choluteca. Aquac Int 4:157-168

Nozais C, Perissinotto R, Tita G (2005) Seasonal dynamics of meiofauna in a South African temporarily-open estuary. Estuar Coast Shelf Sci 62:325-338

> Palmer MA (1988) Dispersal of marine meiofauna: a review and conceptual model explaining passive transport and active emergence with implications for recruitment. Mar Ecol Prog Ser 48:81-91

Perez-Velazquez M, Bray WA, Lawrence AL, Gatlin DM III, Gonzalez-Felix ML (2001) Effect of temperature on sperm quality of captive Litopenaeus vannamei broodstock. Aquaculture 198:209-218

Purwanto H (1997) Economic optimization in prawn farming. PhD thesis, James Cook University, Townsville

Queiroz JF, Boyd CE (1998) Evaluation of a kit for estimating organic matter concentrations in bottom soils of aquaculture ponds. J World Aquac Soc 29:230-233

Ray GL (2007) Thin layer placement of dredged material on coastal wetlands: a review of the technical and scientific literature. ERDC/EL TN-07-1, Army Engineer Research and Development Center, Vicksburg, MS

Ricci C (2001) Dormancy patterns in rotifers. Hydrobiologia 446/447:1-11

Ritvo G, Samocha TM, Lawrence AL, Neill WH (1998) Growth of Penaeus vannamei on soils from various Texas shrimp farms, under laboratory conditions. Aquaculture 163:101-110

Smock LA (1994) Movements of invertebrates between stream channels and forested floodplains. J N Am Benthol Soc 13:524-531

> Street M, Titmus G (1979) The colonisation of experimental ponds by Chironomidae (Diptera). Aquat Insects 1: 233-244

Strickland JDH, Parsons TR (1972) A practical handbook of sea-water analysis. Bull Fish Res Board Can 167:207-211 
Szuster B (2006) Coastal shrimp farming in Thailand: searching for sustainability. In: Hoanh CT, Tuong TP, Gowing JW, Hardy B (eds) Environment and livelihoods in tropical coastal zones. CAB International, Wallingford, p 86-98. Available at: www.iwmi.cgiar.org/publications/ CABI_Publications/CA_CABI_Series/Coastal_Zones/ Hoanh_1845931076-Chapter7.pdf

Virly S, Buisson D, Clough B, Lemmonier H, Richer de

Editorial responsibility: Megan La Peyre,

Baton Rouge, Louisiana, USA
Forges B (2005) Evaluation de l'impact de l'aquaculture de crevettes sur les mangroves de Nouvelle Calédonie. Rapport final, Programme ZONECO, Agence de Développement Economique de la Nouvelle-Calédonie (ADECAL), Nouméa

Yuvanatemiya V, Boyd CE (2006) Physical and chemical changes in aquaculture pond bottom soil resulting from sediment removal. Aquac Eng 35:199-205

Submitted: November 8, 2010; Accepted: July 8, 2011

Proofs received from author(s): August 19, 2011 